\title{
BIOTEKNOLOGI LINGKUNGAN UNTUK PENANGGULANGAN LIMBAH MENGANDUNG KROM
}

\section{Environmental Biotechnology for Treatment of Chrome Contained Wastewater}

\author{
Dwi Andreas Santosa, Tommy Kurniawan, dan F. Dian Lina
}

\author{
Departemen Ilmu Tanah dan Sumberdaya Lahan, Fakultas Pertanian \\ Institut Pertanian Bogor Jalan Meranti Kampus IPB, Darmaga 16680 \\ E-mail: dsantosa@indo.net.id
}

\begin{abstract}
The biotechnological approaches for treatment of wastewater are widely studied within the last two decades. We show that this approach can be used for treatment of Cr-contaminated wastewater. The sulfate reducing bacteria Desulfotomaculum orientis ICBB 1204 is used in a laboratory experiment to treat Cr-contained wastewater from metal plating industry and the oil and gas company, PT VICO, East Kalimantan. After adaption of the bacteria for around 10 days in the wastewater containing $100 \mathrm{ppm} C r$, the process of $\mathrm{Cr}$ reduction took place and the $\mathrm{Cr}$ in the medium were reduced $92.7 \%$ within 20 days. The similar results were achieved on the treatment of PT VICO's wastewater. The Cr content in the wastewater decreased from 6.54-6.76 to 0.08-0.09 ppm and the pH increased from 3 to $5-6$ within 20 days incubation period.
\end{abstract}

Keywords: Cr detoxification, Desulfotomaculum orientis ICBB 1204, sulphate reducing bacteria, wastewater

\section{PENDAHULUAN}

Selain membawa dampak positif, perkembangan teknologi dan industri yang sangat cepat dewasa ini juga membawa dampak negatif. Dampak negatif tersebut terutama berkaitan dengan semakin banyaknya jenis dan jumlah atau volume limbah yang besar sehingga mengakibatkan permasalahan semakin kompleks. Salah satu limbah industri yang merupakan pencemar lingkungan adalah logam berat, diantaranya krom (Cr). Logam ini antara lain digunakan dalam industri pelapisan logam (DepLH, 2003), tekstil dan industri minyak bumi.

Menurut KEP-51/MENLH/10/1995 tentang Baku Mutu Limbah Cair bagi Kegiatan Industri, kadar maksimum $\mathrm{Cr}$ yang diperbolehkan dalam limbah industri adalah 0.5 ppm (MENLH, 1995). Dalam rangka memenuhi baku mutu, limbah harus menjalani proses pengolahan sebelum dibuang ke lingkungan antara lain dengan metode biologi (bioremediasi) dengan menerapkan proses anaerob menggunakan bakteri pereduksi sulfat (BPS). Dalam proses ini, BPS mereduksi sulfat menjadi sulfida. Sulfida yang dihasilkan bereaksi dengan ion-ion logam yang terlarut membentuk logam-sulfida yang mengendap (Germida, 1998). Selain itu, pH larutan limbah juga akan meningkat.

United State Environmental Protection Agency (U.S. EPA) mendata ada 13 logam berat yang merupakan unsur pencemar utama yang berbahaya, yaitu $\mathrm{Sb}, \mathrm{As}, \mathrm{Be}, \mathrm{Cd}, \mathrm{Cr}$,
$\mathrm{Cu}, \mathrm{Pb}, \mathrm{Hg}, \mathrm{Ni}, \mathrm{Se}, \mathrm{Sr}, \mathrm{Ag}$ dan Zn (Suhendrayatna, 2001). Logam berat memasuki lingkungan baik secara alamiah maupun melalui berbagai aktivitas manusia (Alloway, 1995). Semakin banyak logam berat yang digunakan dalam aktivitas kehidupan dengan tidak memperhatikan kelestarian lingkungan maka semakin tinggi potensi logam berat untuk mencemari lingkungan. Banyak dampak keracunan logam berat yang telah terjadi dan merusak ekosistem serta merugikan manusia. Perputaran logam berat dalam ekosistem tanah, air, udara dan organisme dapat dilihat pada Gambar 1.

Krom (Cr) merupakan salah satu logam lunak berwarna keperakan yang berpotensi untuk mencemari lingkungan dan menimbulkan dampak negatif terhadap kehidupan manusia (Gauglhofer dan Bianchi, 1991). Bentuk paling umum dari $\mathrm{Cr}$ adalah $\mathrm{Cr}^{0}, \mathrm{Cr}^{3+}$, dan $\mathrm{Cr}^{6+}$. $\mathrm{Cr}^{3+}$ terdapat secara alami di alam dan bentuk ini merupakan hara essensial bagi tubuh manusia. Atom $\mathrm{Cr}$ dan $\mathrm{Cr}^{6+}$ merupakan hasil dari proses industri. Logam $\mathrm{Cr}$ dalam bentuk $\mathrm{Cr}^{\mathrm{o}}$ digunakan untuk pembuatan baja, sedangkan $\mathrm{Cr}^{6+}$ digunakan untuk pelapisan logam.

$\mathrm{Cr}^{+3}$ merupakan hara essensial yang membantu metabolisme gula, protein dan lemak, namun bila terakumulasi dalam jumlah berlebih akan berbahaya bagi tubuh. Menghirup $\mathrm{Cr}^{6+}$ dalam jumlah berlebih dapat menyebabkan iritasi hidung, hidung berdarah, gangguan perut dan radang, gagal ginjal, kerusakan hati dan pada akhirnya menyebabkan kematian (DHHS, 2000). 


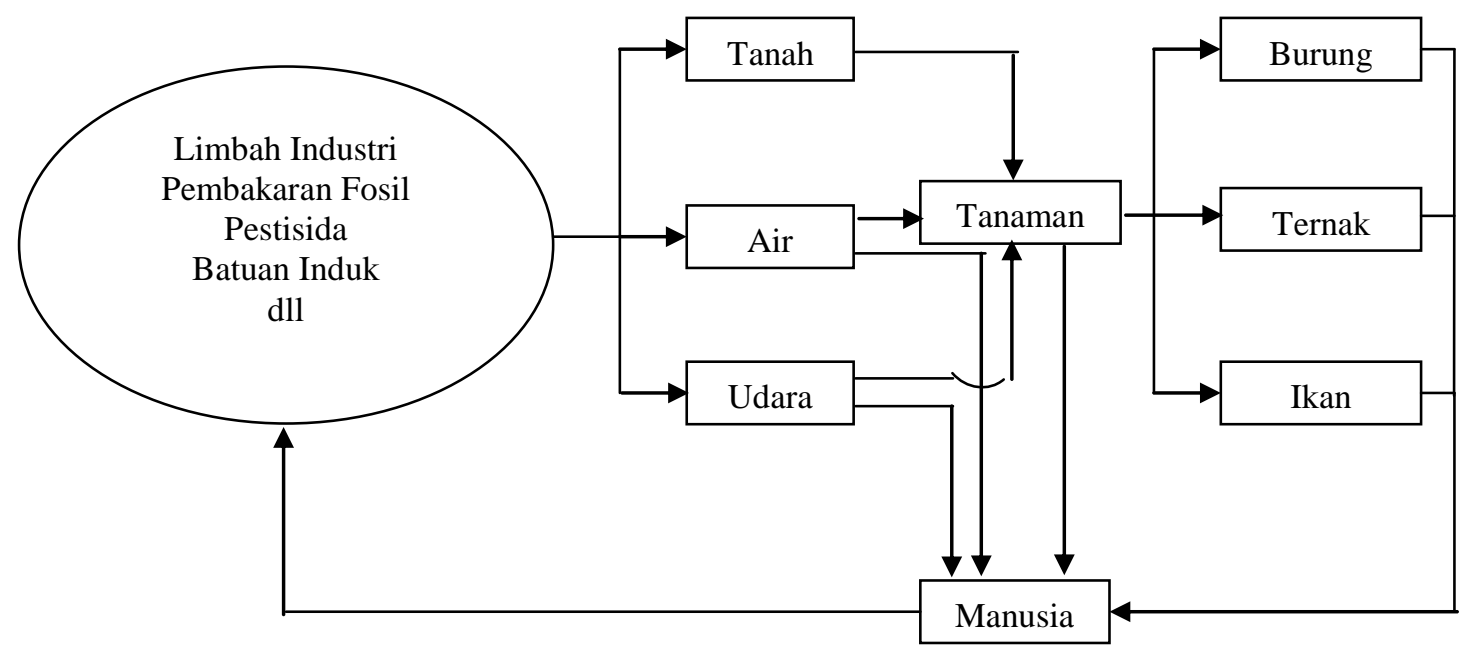

Gambar 1. Sumber Logam Berat dan Perputarannya Dalam Ekosistem Tanah, Air, Udara dan Organisme (Bollag dan Bollag, 1995)

Limbah yang mengandung logam berat perlu didetoksifikasi terlebih dahulu sebelum dibuang ke lingkungan. Pengolahan limbah secara umum dikelompokkan kedalam metode fisik, kimia dan biologi. Penanganan limbah secara biologi menurut Bollag dan Bollag (1995) adalah proses mendegradasi, mengendapkan dan mentransformasi senyawa-senyawa kimia komplek maupun sederhana menjadi bentuk yang tidak berbahaya atau proses detoksifikasi pencemar lingkungan secara biologis. Tanaman dan mikroorganisme dapat digunakan sebagai agen pendetoksifikasi dalam proses tersebut.

Salah satu agen yang dapat digunakan dalam proses pengolahan limbah secara biologis adalah Bakteri Pereduksi Sulfat (BPS). BPS misalnya genus Desulfovibrio dan Desulfotomaculum dalam kondisi anaerob akan mereduksi sulfat dan memproduksi sulfida yang akan bereaksi dengan logam membentuk logam sulfida yang mengendap (Gadd, 1990). Proses pengendapan logam terlarut ini digunakan untuk mengurangi konsentrasi logam dalam air limbah sehingga memenuhi baku mutu yang dipersyaratkan ketika dibuang ke lingkungan.

BPS menggunakan sulfat sebagai penerima elektron dalam proses respirasi anaerobik. Bakteri pereduksi sulfat ini memiliki sifat anaerob sejati dan terdiri dari genus Desulfovibrio, Desulfotomaculum dan Desulfomonas. Proses reduksi sulfat oleh kelompok bakteri tersebut menghasilkan hidrogen sulfida menurut persamaan reaksi :

$$
2 \mathrm{C}_{3} \mathrm{H}_{5} \mathrm{O}_{3}{ }^{-}+\mathrm{SO}_{4}=\stackrel{\mathrm{BPS}}{\longrightarrow} 2 \mathrm{CH}_{3} \mathrm{COO}^{-}+2 \mathrm{HCO}_{3}{ }^{-}+\mathrm{HS}^{-}+\mathrm{H}^{+}
$$

\section{BPS}

$4 \mathrm{H}_{2}+\mathrm{SO}_{4}^{-} \longrightarrow \mathrm{H}_{2} \mathrm{~S}+2 \mathrm{H}_{2} \mathrm{O}+2 \mathrm{OH}^{-}$

BPS dapat tumbuh baik menggunakan donor elektron berupa laktat dan senyawa-senyawa hidrogen. Sulfida yang dihasilkan akan bereaksi dengan ion-ion logam terlarut untuk membentuk sulfida logam yang tidak larut sesuai reaksi :

\section{BPS}

$\mathrm{M}^{2+}+\mathrm{S}^{2-} \longrightarrow \mathrm{MS} \downarrow(\mathrm{M}$ adalah logam ; Gadd, 1999)
BPS yang digunakan dalam penelitian ini adalah isolat hasil isolasi dari Ekosistem Air Hitam, Kalimantan Tengah dengan sandi ICBB 1204. Isolat tersebut merupakan BPS dengan spesies Desulfotomaculum orientis dengan karakteristik yang telah diamati bersifat Gram negatif, berbentuk batang, berpasangan dan membentuk agregat, motil dan hanya tumbuh pada kondisi anaerob (Saida, 1999; Suyasa, 2002).

\section{BAHAN DAN METODE}

Percobaan menggunakan rancangan acak lengkap. Percobaan menggunakan dua sumber limbah yaitu limbah yang berasal dari industri pelapisan logam dan kedua limbah yang berasal dari industri minyak dan gas bumi. Dalam percobaan pertama, derajat kemasaman $(\mathrm{pH})$ dari limbah diatur hingga mendekati 1 dengan $\mathrm{H}_{2} \mathrm{SO}_{4}$ sedangkan kandungan $\mathrm{Cr}$ diatur hingga konsentrasinya mencapai 100 ppm. Dalam percobaan kedua, limbah berasal dari penambangan minyak dan gas bumi PT VICO dan tidak dilakukan pengaturan konsentrasi $\mathrm{Cr}$ dalam limbah. $\mathrm{pH}$ awal yang digunakan dalam percobaan ini adalah 1,3 dan 7. Kemampuan bakteri Desulfotomaculum orientis ICBB1204 dalam menurunkan kandungan Cr dalam limbah dan meningkatkan $\mathrm{pH}$ diuji. Medium yang digunakan untuk menumbuhkan bakteri adalah medium Postgate B dengan komposisi sebagai berikut (g/l): $\mathrm{Na}$ laktat $(3,5), \mathrm{MgSO}_{4}$ $(2,0), \mathrm{NH}_{4} \mathrm{Cl}(0,2), \mathrm{KH}_{2} \mathrm{PO}_{4}(0,5), \quad \mathrm{FeSO}_{4} .7 \mathrm{H}_{2} \mathrm{O}(0,5)$. Medium diterilkan pada suhu $121^{\circ} \mathrm{C}$ tekanan 1 atmosfir selama 15 menit. Percobaan dilakukan selama 30 hari dan Cr dianalisis setiap 5 hari sekali dengan menggunakan $A A S$ (atomic absorption spectrophotometer).

\section{HASIL DAN PEMBAHASAN}

Bakteri yang diberikan mengalami fase lag kira-kira 10 hari. Setelah fase lag terlampaui laju penurunan kandungan $\mathrm{Cr}$ berlangsung sangat cepat, dengan total reduksi sebanyak 92,7 \% selama 30 hari (Gambar 1). Kandungan $\mathrm{Cr}$ diperkirakan akan dibawah $1 \mathrm{ppm}$ bila inkubasi dilanjutkan. 


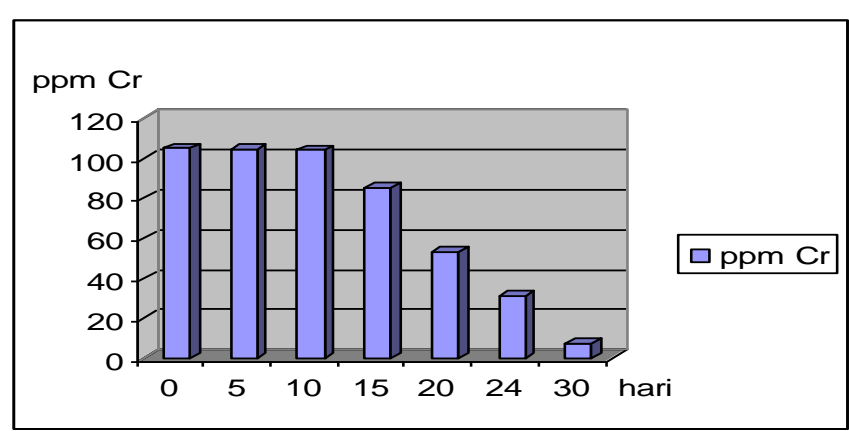

Gambar 1. Penurunan Rata-rata $\mathrm{Cr}$ akibat Inkubasi Limbah Pelapisan Logam ber-Cr dengan menggunakan Bakteri Desulfotomaculum orientis ICBB1204

Selama proses penurunan kandungan $\mathrm{Cr}$ di dalam larutan, sebaliknya terjadi peningkatan $\mathrm{pH}$ dari $\mathrm{pH}$ awal sebesar 1,29 menjadi netral $(6,95)$ pada inkubasi selama 30 hari (lihat Gambar 2).

Aplikasi BPS pada limbah PT. VICO yang mengandung $\mathrm{Cr}$ dalam skala laboratorium menggunakan tabung reaksi/tabung ulir ukuran $10 \mathrm{ml}$ dengan ulangan sebanyak 3 kali. Analisis awal konsentrasi Cr total pada limbah menunjukkan nilai rata-rata 6 ppm.

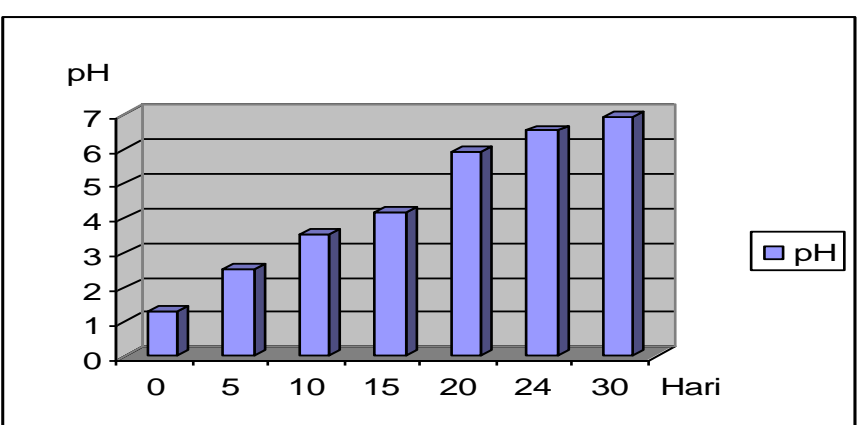

Gambar 2. Peningkatan $\mathrm{pH}$ Akibat Perlakuan Limbah Penapisan Logam ber-Cr dengan Menggunakan Bakteri Desulfotomaculum orientis ICBB1204

Komposisi perlakuan pada tiap tabung reaksi dengan perbandingan 5: $4: 1$ untuk limbah : media : BPS. Inkubasi dilakukan pada $\mathrm{pH} 1,3$ dan 7 selama 20 hari dengan hasil yang terbaik ada pada perlakuan $\mathrm{pH} 3$. Indikasi adanya pertumbuhan BPS adalah perubahan pada tabung reaksi berisi media dari jernih menjadi hitam pekat sebagai akibat pembentukan sulfida logam. Sulfida logam pada percobaan ini merupakan ikatan $\mathrm{CrS}$ yang berbentuk kerak hitam pada dinding dan dasar tabung reaksi, sedangkan air media tetap berwarna jernih (Gambar 3).

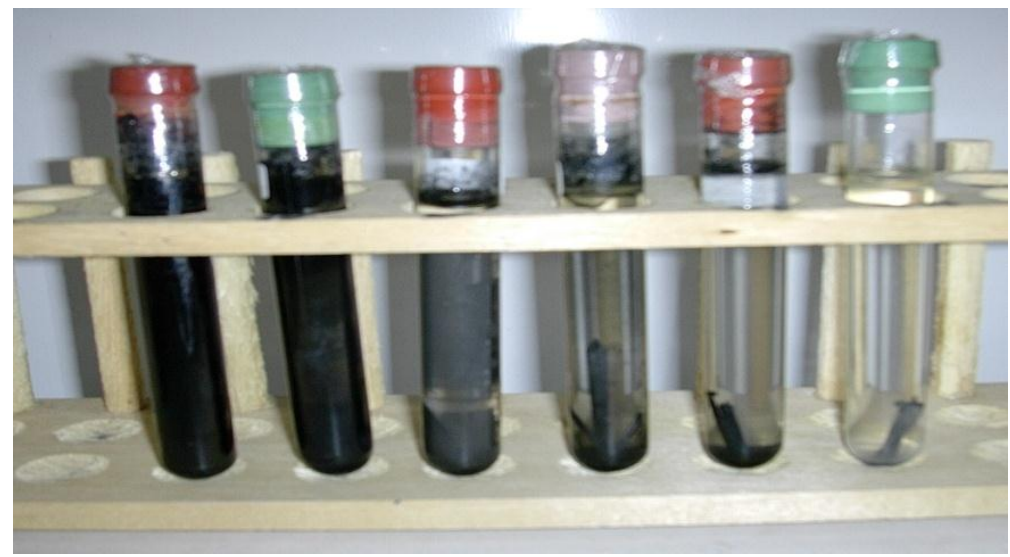

Gambar 3. Proses Pertumbuhan Desulfotomaculum orientis ICBB1204 (dari kanan ke kiri adalah awal pertumbuhan hingga akhir inkubasi)

Pada $\mathrm{pH} 3$ terjadi pertumbuhan BPS pada semua ulangan dengan waktu tercepat antara 10-15 hari, sedangkan pada $\mathrm{pH} 1$ dan $\mathrm{pH} 7$ tidak terjadi pertumbuhan BPS atau mengalami pertumbuhan yang sangat lambat dalam waktu yang lama (>20 hari). Penurunan konsentrasi Cr serta kenaikan $\mathrm{pH}$ limbah hasil eksplorasi minyak dan gas bumi PT VICO setelah diinkubasi selama 20 hari terlihat pada Tabel 1 .

Tabel 1. Penurunan Konsentrasi Cr dan Kenaikan pH pada Limbah Hasil Eksplorasi Minyak dan Gas Bumi PT VICO Setelah Inkubasi dengan Desulfotomaculum orientis ICBB1204 Selama 20 hari

\begin{tabular}{lcccc}
\hline & \multicolumn{2}{c}{ Konsentrasi Cr $(\mathrm{ppm})$} & & $\mathrm{pH}$ \\
\cline { 2 - 5 } Limbah & Awal & Akhir & Awal & Akhir \\
\hline Limbah 1 & 6,76 & 0,09 & 3 & 5 \\
Limbah 2 & 6,54 & 0,08 & 3 & 6 \\
Limbah 3 & 6,55 & 0,08 & 3 & 6 \\
\hline
\end{tabular}

Inkubasi selama 20 hari pada ketiga ulangan menunjukkan penurunan $\mathrm{Cr}$ total yang sangat signifikan (dari 6,54-6,76 menjadi 0,08-0,09) dan telah berada dibawah Nilai Baku Mutu Air Limbah untuk Cr $(<0,5$ ppm) sehingga aman untuk dibuang ke lingkungan.

Parameter lain yang diukur adalah nilai $\mathrm{pH}$. Pada perlakuan menggunakan $\mathrm{pH}$ awal 3 terjadi kenaikan $\mathrm{pH}$ limbah mendekati $\mathrm{pH}$ netral yaitu antara $\mathrm{pH}$ 5-6 sehingga memenuhi nilai baku mutu $\mathrm{pH}$ air limbah sesuai peraturan.

Berdasarkan hasil percobaan tersebut di atas, penggunaan bakteri Desulfotomaculum orientis ICBB1204 memberikan harapan besar untuk memecahkan persoalan limbah industri baik industri pelapisan logam maupun minyak bumi yang mengandung $\mathrm{Cr}$ dengan cara ekonomis, ramah lingkungan dan tidak memerlukan investasi besar. 


\section{KESIMPULAN}

Pendekatan bioteknologi dapat digunakan untuk mengolah limbah industri yang mengandung $\mathrm{Cr}$ hingga kandungannya sesuai dengan baku mutu yang dipersyaratkan oleh pemerintah. Dalam penelitian ini diperlihatkan bahwa bioreaktor yang diberi bakteri pereduksi sulfat Desulfotomaculum orientis ICBB1204 mampu menurunkan kandungan $\mathrm{Cr}$ yang terdapat dalam limbah pelapisan logam sebanyak $92,7 \%$ pada inkubasi selama 30 hari. Dengan teknik yang sama limbah hasil eksplorasi minyak dan gas bumi PT VICO dapat diturunkan hingga $98,8 \%$ pada inkubasi selama 20 hari. Pada kedua jenis limbah tersebut, setelah perlakuan $\mathrm{pH}$ media meningkat sebesar 2 hingga 5,6 satuan $\mathrm{pH}$.

\section{DAFTAR PUSTAKA}

Alloway, B.J. 1995. The origins of heavy metal in soils. In B.J. Alloway (Ed.). Heavy Metals in Soils. Second Edition. Blackie Academic \& Professional.

Bollag, J.M., dan Bollag W.B. 1995. Soil Contamination and the Feasibility of Biological Remediation. In H.D. Skipper and R.F. Turco (Eds.). Bioremediation Science and Applications. Soil Sci Soc Am. Inc.

Darmono. 1995. Logam Dalam Sistem Biologi Makhluk Hidup. Universitas Indonesia Press. Jakarta.

DepLH. 2003. Pengolahan dan Pemanfaatan Limbah Elektroplating. Pengelolaan Limbah Usaha Kecil. Departemen Lingkungan Hidup. www.menlh.go.id/ usaha-kecil/ [diakses 12 Desember 2003].

DHHS. 2000. Case Studies in Environmental Medicine Chromium Toxicity. Agency for Toxic Substances and Disease Registry (ATSDR). U.S. Department Of Health and Human Services. www.atsdr.cdc.gov. [diakses 12 Desember 2003].
Gadd, G.M. 1990. Metal Tolerance. in Clive Edward (Ed). Microbiology of Extreme Environments. First Edition. Open University Press, Buckingham.

Gadd, G.M. 1999. Metal-microbe interactions. Adv. Microb. Physiol., 41:47-92. http://www.dundee.ac.uk/ Biocentre/SLSBDIV7gmg.htm. [diakses 24 September 2003].

Gauglhofer. J dan V. Bianchi. 1991. Chromium. In. Ernest Merian (Ed.). Metals and Their Compounds in the Environment Occurrence, Analysis and Biological Relevance. VCH, Weinheim. New York.

Germida, J.J. 1998. Transformation of Sulfur. In D.M Sylvia, J.J. Fehrmann, P.G. Hartel and D. A. Zuberer. Principles and Applications of Soil Microbiology. Prentice Hall. New Jersey.

Lina, F.D. 2004. Imobilisasi Logam Berat Cr pada Berbagai Konsentrasi Sulfat dengan Desulfotomaculum Orientis ICBB 1204. Program Sarjana. S1. Institut Pertanian Bogor.

MENLH. 1995. Keputusan Menteri Negara Lingkungan Hidup. Nomor:KEP-51/MENLH/10/1995.

http//www.bipedal.go.id./kepmen. [diakses 9 Januari 2004].

Saida. 2001. Karakterisasi dan Uji Aktivitas Isolat Bakteri Pereduksi Asal Ekosistem Air Hitam Kalimantan Tengah. Program Pasca Sarjana. S2. Institut Pertanian Bogor.

Suhendrayatna. 2001. Bioremoval Logam Berat dengan Menggunakan Mikroorganisme; suatu kajian kepustakaan. Seminar on-air Bioteknologi untuk Indonesia. Bab 21:1-14 Februari 2001. Sinergy forum-PPI Tokyo Institute Technology.

Suyasa, W.B. 2002. Peningkatan pH dan Pengendapan Logam Berat Terlarut Air Asam Tambang (AAT) Dengan Bakteri Pereduksi Sulfat Dari Ekosistem Air Hitam Kalimantan. Program Pasca Sarjana. S3. Institut Pertanian Bogor. 